UDC 378.184

JEL I 22, M 11

DOI 10.31375/2226-1915-2020-1-127-134

\author{
Squires V. \\ Associate Professor, Graduate Chair, \\ vicki.squires@usask.ca \\ University of Saskatchewan, Saskatoon, Canada
}

Shakhova O.

Student of Odessa National Maritime University, «Logistic Management» major helena.shakhova@gmail.com

ORCID: 0000-0002-9285-4403

Odessa National Maritime University, Odessa, Ukraine

\title{
ANALYSIS OF INTERNATIONAL STUDENTS' EXPERIENCE THROUGH THE AUTOETHNOGRAPHY METHOD
}

Abstract. Studying abroad becomes more popular with very single year. However, quite often people, while following the perfect image of studying overseas, totally forget about the unexpected challenges they might face abroad, that can make a tremendous impact on their experience. That is why, it is extremely important to consider all the factors that can influence students' physical, emotional, and mental well-being during their studies overseas.

The main research method that is used for this paper is autoethnography which is a qualitative research approach that an author uses for writing about his or her own experience in a specific cultural context. Using autoethnography as the lens, a comparison of an author's experience as an exchange student in Fayetteville State University and as an intern at the University of Saskatchewan, Canada is provided. Quite often autoethnography is not perceived as a scientific method because of its subjectivity - a researcher makes conclusions based on personal perception. That is why one of the ways that researchers use to make their work more credible is ratio of own text with data that was received by other research. For this reason, a literature review and statistics are used to provide context to the topic of international education. Through the use of autoethnography supported by a literature review, this research paper will define the key aspects that international students should pay attention to while choosing a place to study abroad, including differences in living conditions and education in Canada and USA. With the help of a Likert scale, the author grades different factors that make an impact on students' experience abroad, and, thus, defines the best destination for studying overseas. According to an analysis that was provided in the paper, the research highlights the strengths and limitations of different post-secondary institutions in three countries and demonstrates the breadth of experiences that are part of studying in various venues locally, nationally and internationally.

Keywords: autoethnography, university, students, education, experience.

(C) Squires V., Shakhova O., 2020 
УДК 378.184

JEL I 22, M 11

DOI 10.31375/2226-1915-2020-1-127-134

В. Сквайрс професорка

vicki.squires@usask.ca

Університет Саскачевана, Саскатун, Канада

О. Шахова

студентка за спеціальністю «Логістичний менеджмент» helena.shakhova@gmail.com ORCID: 0000-0002-9285-4403

Одеський наиіональний морський університет,

Одеса, Украӥна

\section{АНАЛІЗ ДОСВІДУ \\ МІЖНАРОДНИХ СТУДЕНТІВ ЗА ДОПОМОГОЮ АВТОЕТНОГРАФІЇ}

Анотація. Навчання за кордоном стає більш популярним з кожним роком. Однак досить часто люди, дотримуючись ідеального образу навчання за кордоном, повністю забувають про несподівані виклики, з якими вони можуть зіткнутися за кордоном $i$ які можуть зробити величезний вплив на їхній досвід. Основна мета иього дослідження - надання інформаиії про аспекти, які повинні враховувати студенти під час поӥздки на навчання до іншої краӥни.

Основним методом дослідження, який використовується для даної роботи, є автоетнографія - якісний дослідницький підхід, який автор використовує для опису свого власного досвіду в конкретному культурному контексті. Використовуючи автоетнографію, у даній роботі порівнюється досвід автора як студента за обміном у Державному університеті Фейетвілл у Північній Кароліні, США та в якості стажера в Університеті Саскачевану, Канада. Більш того, огляд літератури та статистика використовуються, щуоб забезпечити більи детальний контекст на тему міжнародної освіти. Відповідно до аналізу, який був наданий у статті, дослідження висвітлює сильні сторони та обмеження різних закладів вищої освіти у трьох краӥнах та демонструє широту досвіду, який частиною навчання в різних місиях на місцевому, національному та міжнародному рівнях.

Ключові слова: автоетнографія, університет, студенти, освіта, досвід
УДК 378.184

JEL I 22, M 11

DOI 10.31375/2226-1915-2020-1-127-134

В. Сквайрс

профессор

Университет Саскачевана, Саскатун, Канада

vicki.squires@usask.ca

Е. Шахова

студентка по специальности «Логистический менеджмент»

Одесский национальный морской университет, Одесса, Украина

\section{АНАЛИЗ ОПЫТА \\ МЕЖДУНАРОДНЫХ СТУДЕНТОВ С ПОМОЩЬЮ АВТОЭТНОГРАФИИ}

Аннотация. Обучение за рубежом становится всё более популярным с каждым годом. Однако довольно часто люди, следуя идеальному образу обучения за рубежом, полностью забывают о неожиданных проблемах, с которыми они могут столкнуться в других странах, что может оказать огромное влияние на их опьты. Основная иель этого исследования предоставить информацию об аспектах, которые студенты должны учитывать при поездке в другую страну для обучения.

Основным методом исследования, который используется в данной статье, является автоэтнография, которая представляет собой качественный исследовательский подход, который автор использует для описания своего собственного опьта в конкретном культурном контексте. Используя автоэтнографию, приводится сравнение опыта автора в качестве студента по обмену в государственном университете Фейетвилля в Северной Каролине, США и в качестве стажера в университете Саскачевана, Канада. Кроме того, в исследовании используются обзор литературы и статистика, чтобы обеспечить более детальный контекст для темы международного образования. Согласно анализу, который был представлен в статье, исследование подчеркивает сильные и слабые стороны различных учреждений высшего образования в трех странах и демонстрирует иироту опьта, который является частью обучения в различных местах на местном, национальном $u$ международном уровнях.

Ключевые слова: автоэтнография, международный, студенты, образование. 
Problem statement. Studying abroad is challenging. Despite these well-documented difficulties, young people from different countries are eager to study overseas, and the main reason why is not only the access to highquality education, but being an international student also equals an opportunity to travel the world, explore new cultures, expand career opportunities, and make lifelong friends with totally differrent backgrounds [1]. However, despite the positive side of international education, young people can face different challenges they could never expect at their home countries [2].

Originally coming from Ukraine, I spent four months as an exchange student in North Carolina, USA and three months as an intern at the University of Saskatchewan in Saskatoon, Canada. Facing different obstacles while being far away from home made me understand how important it is to provide international students with aspects and information they should consider before going abroad that will help them to make their stay as smooth as possible.

Review of the latest researches and publications provided a foundation for the research. Recently an approach called autoethnography became another way to conduct a qualitative study. It is a method that uses the description and analysis of 'auto' or personal experience to understand 'ethno' or culture [3]. This method takes the author as the subject of the research $[4 ; 5]$. A researcher writes about experience that could only happen according to the specific cultural or social conditions that are being studied, or while having a particular cultural experience According to Ricci, autoethnography «allows the reader (and the writer) to experience something new - to feel, to learn, to discover, to co-create» [6]. Despite the fact that this method is about recreating emotions and feelings of a narrator, its main goal is to learn about the culture, and this is the main difference between autoethnography and autobiography [7]. While writing an autoethnography, an author may use different recourses', such as journals, textbooks, videos, or interviews with other people to recall the facts.

As any research method, autoethnography has its advantages and limitations. This method provides the ability to have access to rich data and get insightful information from authors' inner world [8;9]. Moreover, easy access to data is another advantage that makes this exact method extremely convenient to use; the author has to describe own experiences and reflections. Counting the fact that in the end of the study, the researchers analyzes their own story, the conclusions might be not as broad as while comparing different resources [10; 11]. Additionally, autoethnography requires honesty, and a narrator who is not ready to fully open himself or herself will not be able to create a comprehensive research and analyse it. However, despite all the limitations, there is another crucial advantage that is definitely worth mentioning. Autoethnography gives readers an ability to «reflect on and emphasize with» what is being described by the author, and it is definitely much easier to do when you are reading a real story, not just facts and numbers [12].

Tasks of the research. The main goal of this research, using an autoethnographic approach, is to provide information on aspects that students should consider when going to study to another country. The main objectives of 
this research are: a) explain the autoethnography method; b) compare three countries from an international student's perspective based on the living conditions of the country and its educational system.

The basic material of the research. While considering studying abroad, it is important for students to pay attention not only to the school that is going to be attended but also to living conditions of the country where the studies are going to be held. In this paper, the living conditions aspect consists of different factors, such as weather conditions, transportation, safety, lifestyle, and accommodation outside of the campus. As for the educational part, it is important to mention different elements, such as a country's educational system, university itself, diversity on campus, attitude towards international students, and support centers.

In order to compare experiences that I (author) have had both during my stay as an exchange student in the USA and as an intern in Canada, the table of quantitative indicators was created. After studying for three years at the university in Odesa, Ukraine, it was possible to evaluate what can make international students choose Ukraine as their destination for education abroad. Each aspect that was described in the research paper can be rated on a Likert scale from zero to ten, where zero is the worst for an international student experience and ten is the best. Also, it is important to understand which factors can influence the experience of international students more than the others, and for that an importance factor coefficient was provided. The bigger the number is, the bigger impact this indicator makes on international students, from my perspective. A total number for all of the importance factors must equal one. The first table is referred to living conditions that includes aspects such as weather conditions, transportation, safety, lifestyle, and accommodation outside of the campus.

Table 1

Students' living conditions in Canada, USA, and Ukraine

\begin{tabular}{|c|c|c|c|c|}
\hline \multirow{2}{*}{ Indicator } & \multirow{2}{*}{$\begin{array}{l}\text { Importance } \\
\text { factor, } k\end{array}$} & \multicolumn{3}{|c|}{ Grade } \\
\hline & & Saskatoon & Fayetteville & Odessa \\
\hline Weather conditions & 0,3 & 4 & 8 & 8 \\
\hline Transportation & 0,2 & 7 & 7 & 6 \\
\hline Safety & 0,3 & 7 & 3 & 6 \\
\hline Lifestyle & 0,1 & 8 & 6 & 9 \\
\hline $\begin{array}{l}\text { Accommodation } \\
\text { outside of the campus }\end{array}$ & 0,1 & 8 & 8 & 8 \\
\hline Total & 1 & 32 & 31 & 37 \\
\hline
\end{tabular}

Source: Own elaboration 
After doing calculation, considering the importance factor, it turned out that living conditions in Odessa, Ukraine are better than in Saskatoon, Canada and Fayetteville, USA:

Saskatoon: $\quad 4 \cdot 0,3+7 \cdot 0,2+7 \cdot 0,3+$ $+8 \cdot 0,1+8 \cdot 0,1=6,3$

Fayetteville: $\quad 8 \cdot 0,3+7 \cdot 0,2+3 \cdot 0,3+$ $+6 \cdot 0,1+8 \cdot 0,1=6,1$ $+8 \cdot 0,1=7,1$

Odessa: $8 \cdot 0,3+6 \cdot 0,2+6 \cdot 0,3+9 \cdot 0,1+$

Knowing that quality of life is much higher in the USA and Canada than it is in Ukraine, it is quite surprising to see that living conditions for international students are better in Odessa, Ukraine. The indicator «weather conditions» has a big impact and thus has been assigned a bigger importance factor $(0,3)$. Odessa has a temperate climate with subtropical features, mild winters, relatively long springs, hot summers, and long warm autumns.

Considering transportation, local transport might be inconvenient some- times due to the lack of GPS applications to track buses. However, it is quite easy to travel around Ukraine with the use of trains and buses, that are extremely cheap; these considerations give Odessa six points for transportation. A lifestyle indicator in Odessa received the highest grade - nine. It is not only connected to the huge amount of places to visit during leisure time, but also to rich history of the city that can be explored through the large number of theaters and museums. Having great climate conditions helps Odessa's citizens to live an active lifestyle, one that almost always brings them to the seashore.

The main aspect why people choose to study abroad is a high-quality education, so it is important to compare all the aspects of this area in the USA, Canada, and Ukraine. The table 2 includes the education system, the university itself, diversity, international students, and support centers.

Table 2

Higher education in Canada, USA, and Ukraine

\begin{tabular}{|l|c|c|c|c|}
\hline \multirow{2}{*}{\multicolumn{1}{c|}{ Indicator }} & Importance & \multicolumn{3}{c|}{ Grade } \\
\cline { 3 - 5 } & factor, $k$ & Saskatoon & Fayetteville & Odessa \\
\hline Education system & 0,2 & 10 & 8 & 3 \\
\hline University & 0,3 & 9 & 7 & 4 \\
\hline Diversity & 0,1 & 8 & 5 & 4 \\
\hline International students & 0,2 & 8 & 3 & 4 \\
\hline Support centers & 0,2 & 8 & 6 & 1 \\
\hline Total & 1 & 35 & 30 & 15 \\
\hline
\end{tabular}

Source: Own elaboration

Saskatoon is better in terms of the education system, considering the facts, such as tuition, ratio of public and private colleges, and admissions pro- cess. Moreover, comparing the University of Saskatchewan (U of S), Fayetteville State University, and Odessa National Maritime University, the $\mathrm{U}$ of $\mathrm{S}$ 
received a higher grade according to different world-known rankings, such as QS and Times Higher Education. Considering diversity, Fayetteville State University is one of the best in the country in terms of age diversity; however, ethnic backgrounds of students do not vary a lot. At the same time, University of Saskatchewan is paying a lot of attention towards this topic and is always open to people with totally different backgrounds. The International students' indicator includes everything considering this group of people, starting from the amount of foreigners at the university and ending with services provided for them. Unfortunately, the grade of Fayetteville State University is quite low not only because of the decreased dynamics in terms of students from all over the world, but also because of the lack of programs for foreigners. Odessa National Maritime University currently has 300 international students and provides them with Russian and Ukrainian language classes before entering the university; however, during obtaining a degree this group of people does not receive a lot of support. Last but not least, support centers are an integral part of the University of Saskatchewan and an indicator that should be definitely worked on more at Fayetteville State University and Odessa National Maritime University.

After evaluating all the aspects and considering their importance factor, it was proved that education in Saskatoon, Canada is more beneficial for the experience of international students, than it is in Fayetteville, USA or Odessa, Ukraine:

Saskatoon: $\quad 10 \cdot 0,2+9 \cdot 0,3+8 \cdot 0,1+$ $+8 \cdot 0,2+8 \cdot 0,2=8,7$

Fayetteville: $8 \cdot 0,2+7 \cdot 0,3+5 \cdot 0,1+$ $+3 \cdot 0,2+6 \cdot 0,2=6$

Odessa: $3 \cdot 0,2+4 \cdot 0,3+4 \cdot 0,1+4 \cdot 0,2+$

$+1 \cdot 0,2=2,8$

In order to make conclusions regarding the place that is more beneficial for international students' experience, there is a need to find an average number for both aspects (living conditions and education) through using an importance factor (Table 3). I believe that both living conditions and education are extremely important aspects that influence each other. Thus, a student cannot focus on studies while not feeling safe, and studying at the university with low-quality education cannot make up for good weather conditions and convenient transportation. So, an importance factor of both indicators equals 0,5 .

Table 3

Total grade for living conditions and education in Canada, USA, and Ukraine

\begin{tabular}{|l|c|c|c|c|}
\hline \multirow{2}{*}{\multicolumn{1}{c|}{ Indicator }} & Importance & \multicolumn{3}{c|}{ Grade } \\
\cline { 3 - 5 } & factor, $k$ & Saskatoon & Fayetteville & Odessa \\
\hline Living conditions & 0,5 & 6,3 & 6,1 & 7,1 \\
\hline Education & 0,5 & 8,7 & 6 & 2,8 \\
\hline Total & 1 & 15 & 12,1 & 9,9 \\
\hline
\end{tabular}

Source: Own elaboration 
Thus, after providing an analysis on two important aspects that are necessary while choosing a place to study abroad, it was proved that the best place for international students' experience in general out of three higher institutions that were analyzed is the University of Saskatchewan in Canada:

Saskatoon: $6,3 \cdot 0,5+8,7 \cdot 0,5=7,5$

Fayetteville: $6,1 \cdot 0,5+6 \cdot 0,5=6,05$

Odessa: $7,1 \cdot 0,5+2,8 \cdot 0,5=4,95$.

Despite the fact, that living conditions in Odessa, Ukraine can bring the best experience for international students, because of the low grade on the education aspect, an overall impression that students will form is not going to be as positive as at the University of Saskatchewan in Canada or at Fayetteville State University in the USA.

Conclusions. Due to the increasing number of people who are eager to study overseas, it is extremely important to spread information about the aspects they should consider before going to another country that can make the learning process more effective and efficient.

Through using the autoethnography method that helps to reflect on my own experience, feelings, and emotions in specific cultural conditions, it was possible to share the realities of being an exchange student of Fayetteville State University, USA and intern at the University of Saskatchewan, Canada. Despite the fact, that quite often students mostly pay attention only to the university that will be attended, another part that is not less important is living conditions. After analysis, it became clear, that based on the author's subjective perception, living conditions in Odessa, Ukraine are better, especially when it comes to weather and lifestyle. Thus, Odessa can be considered more beneficial for international students' experience out of three cities in terms of this specific aspect. Another important part of the review was connected to education. After the comparative analysis, a few indicators, such as the education system, the university, attitude towards international students, and support centers at the U of S, Saskatoon had a higher grade than Fayetteville, USA and Odessa, Ukraine. After taking an average grade of both education and living conditions aspect, it was proved that international students can get a more positive and enhancing experience from studying at a Canadian university, the University of Saskatchewan, than at the Fayetteville State University in the U.S. or Odessa National Maritime University in Ukraine.

There are other important aspects people pay attention to while applying for different universities abroad, such as financial aid, scholarships, hobbies, and interests. However, while considering going overseas, a student should be really attentive towards the aspects that were mentioned before in the paper, such as living conditions and education, as they seem to have the biggest impact not only on academic success of incoming students, but also their physical and mental well-being. 


\section{REFERENCES}

1. Lipson, C. (2008). Succeeding as an International Student in the United States and Canada (1st ed.). Chicago: University of Chicago Press.

2. Averett, P., \& Soper, D. (2011). Sometimes I Am Afraid: An Autoethnography of Resistance and Compliance. The Qualitative Report, 16(2), 358-376. Retrieved from https://nsuworks.nova.edu/tqr/voll6/iss $2 / 3$

3. Bochner, A.P., \& Ellis, C. (1996). Talking over ethnography. In C. Ellis \& A.P. Bochner (Eds.), Composing Ethnography: Alternative Forms of Qualitative Writing (p.13-45).Walnut Creek, CA: Alta Mira Press.

4. Richardson, Laurel. (2000). Evaluating Ethnography. Qualitative Inquiry - QUAL INQ. 6. 253-255. 10.1177/107780040000600207.

5. Richardson, L. (2000). My Left Hand: Socialization and the Interrupted Life. Qualitative Inquiry, 6(4), 467-473. doi: 10.1177/107780040000600403

6. Ricci, R. (2003). Autoethnographic verse: Nicky's boy: A life in two worlds. The Qualitative Report, 8(4), 591-597. Retrieved from http://www.nova.edu/ssss/ QR/ QR8-4/ricci.pdf

7. Austin, J. and Hickey, A. (2007). Autoethnography and Teacher Development. International Journal of Interdisciplinary Social Sciences, 2 (2). pp. 369-378.

8. Pavlenko, A. (2002). Narrative study: whose story is it anyway? TESOL Quarterly, 36, 213- 218.

9. Pavlenko, A. (2007). Autobiographic narratives as data in applied linguistics. Applied Linguistics, 28, 63-188.

10. Ellis, C. (2004). The ethnographic I: A methodological novel about autoethnography. Walnut Creek, CA: AltaMira Press.

11. Sale, J., \& Thielke, S. (2018). Qualitative research is a fundamental scientific process. Journal Of Clinical Epidemiology, 102, 129-133. Doi: 10.1016/j.jclinepi. 2018.04.024

12. Méndez, M. (2013). Autoethnography as a research method: Advantages, limitations and criticisms. Colombian Applied Linguistics Journal, 15(2), 279. Doi: 10.14483/ udistrital.jour.calj.2013.2.a09

Article received 28.12.2019

Reference a JournalArtic: Squires, V. \& Shakhova, O. (2020). Analysis of international students' experience through the autoethnography method. Development of management and entrepreneurship methods on transport, 1 (70), 127-134. DOI 10.31375/2226-1915-2019-4-127134. 